\title{
A Return to 'Civilisational Geopolitics' in the Mediterranean? Changing Geopolitical Images of the European Union and Turkey in the Post-Cold War Era
}

\section{PINAR BILGIN}

To cite this article: PINAR BILGIN (2004) A Return to 'Civilisational Geopolitics' in the Mediterranean? Changing Geopolitical Images of the European Union and Turkey in the Post-Cold War Era, Geopolitics, 9:2, 269-291, DOI: 10.1080/14650040490442863

To link to this article: https://doi.org/10.1080/14650040490442863

\section{Published online: 10 Aug 2010.}

\section{Submit your article to this journal $\llbracket$}

Џ Article views: 655

Citing articles: 19 View citing articles $[\pi$ 


\title{
A Return to 'Civilisational Geopolitics' in the Mediterranean? Changing Geopolitical Images of the European Union and Turkey in the Post-Cold War Era
}

\author{
PINAR BILGIN
}

The prevalence of the discourse of ideological geopolitics during the Cold War meant that both Turkey and the EU belonged to the West by virtue of their ideological orientation. In the absence of this prevalent geopolitical discourse, both the EU and Turkey have spent the 1990s trying to locate themselves geographically. Drawing on the literature on critical approaches to political geography and international relations, this article seeks to answer the question of whether the EU's post-Cold War security discourse on the Mediterranean in general and on relations with Turkey in particular point to a return to the earlier discourse of civilisational geopolitics. The article also presents a reading of Turkish policy makers' attempts to resist EU's representation of Turkey in 'non-Europe' (as with the 'Middle East' or the 'Mediterranean') as boundaryproducing practices which have served to underline the boundaries between the 'West' and the 'non-West'.

The fall of the Berlin Wall and the dissolution of the Soviet Union gave rise to a feeling of ontological insecurity as to how to organise world politics when drawing our mental maps. As John Agnew has argued, for a while there was a "current of nostalgia for the "good old days" when the East was East and the West was West and never the twain should meet'. ${ }^{1}$ In the early 1990s this statement seemed true for Turkish policy makers, who began to question Turkey's identity and its geopolitical location. ${ }^{2}$ The post- 1989 environment was received rather more favourably in the European Union, ${ }^{3}$ which increased its pace towards 'becoming Europe'. ${ }^{4}$ This article analyses the changing geopolitical images of Turkey and the European Union in the post-Cold War era. Drawing on the literature on critical approaches to political geography ${ }^{5}$ and international relations, ${ }^{6}$ the article seeks to answer the question of whether the European Union's postCold War Mediterranean policy in general and its relations with Turkey in particular point to a return to the discourse of civilisational geopolitics.

Pinar Bilgin, Department of International Relations, Bilkent University, Ankara 06533, Turkey. E-mail: <pbilgin@bilkent.edu.tr>. 
'Civilisational geopolitics' is one of the three discourses identified by John Agnew in Geopolitics: Revisioning World Politics, where he uses a threefold periodisation to explain the development of geopolitical thought from the early nineteenth century until the end of the Cold War. ${ }^{7}$ The discourse of civilisational geopolitics is the one in which different parts of the world were categorised in people's mental maps according to the 'civilisation' to which people that inhabited that 'region' were perceived to belong. Next came 'naturalised geopolitics' in the nineteenth and early twentieth centuries, when geopolitics as a separate discipline began to flourish. The third era Agnew identifies is the 'ideological geopolitics' of the Cold War years, when the world was divided in line with the ideological leanings of individual governments. With the end of the Cold War, the prevalence of the discourse of ideological geopolitics has come to an end, thereby leaving a vacuum that is yet to be occupied by a single geopolitical discourse. ${ }^{8}$

So far, the European Union's attempts to locate itself in post-Cold War terrain of world politics have involved the re-inscription of a European identity via foreign and security policies that involved the adoption of a two-pronged policy of expanding towards the East whilst containing the South. Whereas the prior involves the exporting of the EU's own security-building model to the East, the latter has entailed the EU's almost single-handed construction of a Mediterranean region via the Euro-Mediterranean partnership scheme. The ambivalence in the EU policy makers' approach to the issue of Turkey's membership, when coupled with the EU's mid-1990s approach to Turkey within a Mediterranean (i.e. Euro-Mediterranean partnership) framework, led some in Turkey to wonder whether in the minds of EU policy makers the boundaries of Europe were being drawn along civilisational lines. ${ }^{9}$ The perception of Turkish policy makers was that Turkey was being judged by 'different criteria than other countries' and that "the "Iron Curtain" that once divided Europe was being replaced by a "cultural/religious iron curtain", ${ }^{10}$

This perception remains, notwithstanding the 1999 (Helsinki Summit) decision of the European Union to recognise Turkey as a candidate country and the 2002 (Copenhagen Summit) decision to declare December 2004 as the date to review Turkey's application and begin entry talks 'without delay', provided that Turkey met the EU criteria. ${ }^{11}$ Indeed, the Copenhagen decision divided Turkey's public opinion into 'optimists' and 'pessimists'. The policy makers head the optimist camp, having declared the EU decision as Turkey's 'second best' option and a minor victory. ${ }^{12}$ The pessimists, on the other hand, have argued that the decision bore out the EU policy-makers' 'failure to overcome their prejudices' against Muslim Turkey, ${ }^{13}$ and that Turkey is being 'lulled into thinking that it will one day become an EU member'. ${ }^{14}$

It is indeed possible to view the Helsinki and Copenhagen summit decisions and the invitation extended to Turkey to participate in the convention on 
the future of the European Union as suggesting that the EU is open to the idea of Turkey's membership provided that Turkey fulfils the necessary requirements. Yet every time an EU policy maker makes an ambivalent statement it is perceived (by the pessimists and optimists alike) as a challenge to Turkey's 'European vocation' and evidence of EU prejudices against Muslim Turks. (An example is Valéry Giscard d'Estaing's comment that 'Turkey's capital is not in Europe...95 per cent of its population is outside Europe, it is not a European country'. ${ }^{15}$ ) What often goes unnoticed is the way in which Turkey's policy makers themselves resort to the discourse of civilisational geopolitics in an attempt to locate themselves in Europe as opposed to the Mediterranean or other non-Western geographical locale. Thus, whilst criticising their EU counterparts for erecting walls between European and Islamic or Western and non-Western peoples, Turkey's policy makers, at times, engage in similar 'boundary-drawing practices' ${ }^{16}$ between 'Turks' and other 'Islamic' and/or 'non-European' peoples. ${ }^{17}$

In search for an answer to the question of whether the discourse of civilisational geopolitics is likely to prevail in the post-Cold War era, this article will limit itself to Turkey-EU relations and their respective policies towards the Mediterranean. The article falls into two parts. The first part will look at the European Union's construction of the Mediterranean as a region and ask whether the EU's post-Cold War policies could be viewed as a return to the discourse of civilisational geopolitics. In the second part, Turkish policy makers' reactions to these developments will be analysed within the context of their efforts to locate Turkey geographically in the post-Cold War map of world politics. The concluding part will cast doubt upon the potential for the adoption of an alternative security discourse by the European Union and Turkey in the post-11 September era.

\section{The European Union and the 'Mediterranean'}

\section{The EU's Two-Pronged Approach to Security Building in its Peripheries}

During the 1990s, the European Union adopted a twofold approach to help build security in its peripheries. To help maintain security in the southern periphery, EU policy makers initiated the Euro-Mediterranean Partnership (EMP) scheme in an attempt to encourage inter-state cooperation and increase regional interdependence as a means of maintaining stability in the Mediterranean. To maintain security in the eastern periphery the EU has sought to export its own security-building model to many former Warsaw Pact members as well as Malta and Cyprus (and Turkey since December 1999). The EU's own security-building model is different from security understood and practised as territorial defence (be it the defence of national 
borders or bloc boundaries, as with NATO during the Cold War). The project of European integration itself has served as a security policy through which member states were bound in a "network of interdependence which made recourse to military means of resolving disputes progressively more difficult'. ${ }^{18}$ Viewed as such, the widening of the European Union to take in new members has meant the EU's exporting of its own security-building model to its eastern periphery. The following analysis of the EU's differentiated approach to security building in its eastern and southern peripheries substantiates the argument that in the immediate aftermath of the Cold War the European Union sought to re-inscribe a European identity partly by inventing a Mediterranean other. Indeed, in the EU discourse the former Warsaw Pact countries are presented as 'returning to Europe' ${ }^{19}$ - Europe being a 'zone of peace' - whereas the Mediterranean is presented as a 'zone of conflict' - an area that should be contained.

\section{The Making of the Mediterranean}

Mediterranean littoral peoples and societies were conceived as constituting parts of a total called the 'Mediterranean' in ancient Greece. According to Thierry Hentch, the first uses of the concept 'West' referred to peoples, societies and states surrounding the Mediterranean, whereas lands further to the east and south constituted the 'East'. ${ }^{20}$ Following the Muslim conquest/invasion of the territories to the south of the Mediterranean (as well as Asia Minor, Malta and Spain) and the gradual emergence of the idea of 'Europe', the construct referred to as the West shifted further westwards and those peoples, societies and states located to the south of the Mediterranean Sea came to be included in the (now vast) entity called the East. ${ }^{21}$ The solidification of the idea of Europe took place during the era of civilisational geopolitics although Europe as a continent predates this period. ${ }^{22}$ Following the 'discovery' of other continents and the encounter with their native peoples, the idea of Europeanness was further reinforced. As Jacques Attali argued in 1492, the discovery of the 'American continent' made a significant impact on the development of a European consciousness. ${ }^{23}$

Even after the dissolution of the unity of the Mediterranean the ties that bound Mediterranean peoples and societies remained, as evidenced in the works of Fernand Braudel, who provided exceptional accounts of the economic and cultural history of the Mediterranean world. ${ }^{24} \mathrm{~A}$ belief in the cultural unity of the Mediterranean survived after these economic links grew weaker during the Age of Discovery and especially after the decline of the Silk Road as the route to the East. Indeed, as Paul Salem has maintained, among the Mediterranean littoral countries of the Arab world, Egypt and Lebanon remained more in touch with the Mediterranean dimension of their identity than others. ${ }^{25}$ For instance, during the 1950s, some Lebanese nationalist thinkers voiced arguments 
favouring identification with the Mediterranean. During this period, Lebanese intellectuals considered the Mediterranean identity as a tool for de-emphasising their links with the Arab-Islamic world whilst claiming affinity with Europe and the West. ${ }^{26}$ In Egypt, following independence, many Western educated and/or oriented individuals advocated playing up Egypt's Mediterranean identity as it was perceived to be 'neither completely European or Western nor completely divorced from the Arab-Islamic world'. ${ }^{27}$ The Mediterranean dimension of Egyptian identity was played down in the post-Second World War era when it joined the League of Arab States and participated in the Arab force constituted to fight Israel in 1948. Following Gamal Abdel Nasser's coming to power in 1954, debates about the Mediterranean dimension of Egypt's identity died down, only to be revived after his death. ${ }^{28}$

As Tunisia, Algeria and Morocco gained independence there emerged more non-European Mediterranean littoral states, thereby enabling Egyptian intellectuals to put forward their arguments in a more confident manner. North African intellectuals have also favoured identification with the Mediterranean as a way of reinforcing the distinctiveness of the Maghreb's Arab-Berber ethnic mix and underlining historical links with Europe in general and France in particular. ${ }^{29}$ In other words, 'Mediterranean', as an alternative spatial representation, was used by the Maghreb intellectuals as a means of inscribing their identity in distinction to a Mashreq other.

\section{The EU's Mediterranean Policies}

Notwithstanding these early origins, it was the European Union that almost single-handedly sought to (re)construct the Mediterranean as a region in the last quarter of the twentieth century. Aforementioned accounts of the past unity of the Mediterranean served as myths that bolstered EU policy-makers' efforts to construct a security zone that includes Europe and the geographically closer North African states.

It is worth noting that the argument here takes the mutually constitutive relationship between foreign and security policy discourses and geographical representations as its starting point ${ }^{30}$ the assumption being that regions are geopolitical representations that are constructed to aid in thinking about and organising economic and security relations in different parts of the world. Be it an external actor constructing a region to serve its strategic interests (as with the United States 'constructing' the 'Middle East') $)^{31}$ or local actors engaging in region building (as in Western Europe) 'regions are imagined communities' ${ }^{32}$

In view of that, the conference at which an earlier version of this article was presented ('Third Mediterranean Social and Political Research Meeting') could also be considered as part of an attempt to re-inscribe the Mediterranean as a region and 'disseminate this imagination to as many other people as possible' - especially to those who act as opinion-formers in their countries. 
What follows is an analysis of the European Union's 1990s attempt to construct a 'Mediterranean' region-via the Euro-Mediterranean Partnership (EMP) process.

The EU's interest in the 'Mediterranean' began to evolve in line with a change in its conceptions and practices of security during the 1970s. The so-called Euro-Arab dialogue was first established after the 1973 Arab-Israeli war and OPEC oil embargo. Although a number of cooperative schemes such as the European Union's Overall Mediterranean Policy of setting up bilateral agreements with sub-regional organisations such as the Gulf Cooperation Council (GCC) and the Arab Maghreb Union (AMU) were initiated during this period, Euro-Arab relations did not proceed any further, partly because of the mistrust caused by some European states' colonialist background and partly due to the bipolar template imposed onto regional security dynamics. ${ }^{33}$

The strengthening of the European Union and the slow progress towards a common foreign and security policy, as well as the end of the Cold War (which gave the EU a freer hand vis-à-vis the United States), were major factors that enabled the European Union to move towards a policy relatively independent of the United States and more in concert with its own domestic security concerns. ${ }^{34}$ What was perhaps more significant was the context created by the change in the societies of EU member states due to the growth of Middle Eastern diasporas in Western Europe.

The mid-1980s saw the increase in political violence by clandestine organizations on European soil. This, in conjunction with the Iranian revolution and the Middle East situation, served to reinforce this climate of anxiety and turn the focus not towards all immigrants, but on those coming from Islamic countries swept up in the wave of re-Islamization, or countries in the middle of civil war. Islam, especially when it reached the Maghreb, was seen as a direct threat not only for these countries but for Europe too. ${ }^{35}$

This has led EU policy makers to re-think their priorities and come to consider stability in the Middle East (especially the geographically closer North Africa) as an integral part of 'security in Europe'. ${ }^{36}$ Accordingly, EU policy makers have sought to create cooperative schemes with the Mediterranean-rim countries of the Middle East (that is, those areas that are 'closer to home') to encourage and support economic development and growth. The expectation has been that this would help reduce refugee flows from the Middle East to Western Europe and prevent regional conflicts being exported to the EU.

\section{EU's Mediterranean Policies as 'Boundary-Producing Practices'}

It has so far been argued that the Mediterranean has been (re)constructed by the European Union in the post-Cold War era to help maintain security in Europe. When EU security intellectuals speak of security in the Mediterranean, the 
referent for security is not necessarily the Mediterranean but Europe. The Euro-Mediterranean project, in this sense, has been instrumental in following a policy of containment by the European Union.

What is meant by containment here is not the conventional understanding of this practice (as in US containment of the Soviet Union during the Cold War). On the contrary, EU policy makers are of the conviction that 'economic, political and diplomatic engagement' with their Mediterranean counterparts would be of "greater relevance ${ }^{37}$ than resorting to Cold War-style containment policies of isolation (as with US 'dual containment' policy towards Iran and Iraq). This is reflective of a broader conception of security (inclusive of its non-military as well as military dimensions) that is at the root of the European Union's policies. As François Heisbourg has noted:

Although the Europeans are just as prone - and possibly even more so, for reasons of proximity - as the Americans to emphasise combined regional dangers of militant fundamentalism and terrorism (not least in Algeria, a prime French security concern), they do not usually see these as essentially military challenges. ${ }^{38}$

For, when the problem at hand is necessarily an economic and social one, the military instrument might not be the best means to use. Since a major concern of EU policy makers is maintaining domestic security within the European Union especially in the face of rising xenophobia, they feel the need to resort to economic and political (as opposed to purely military) instruments. Yet this policy could nevertheless be characterised as one of containment in that, through cooperation and dialogue, the European Union is aiming to help to solve (or at least freeze) some Mediterranean problems so that these problems would not threaten security in Europe directly (through military or terrorist threats) or indirectly (through increasing migration and/or restlessness within the Mediterranean diaspora in the Union).

Second, by way of (re)constructing the Mediterranean, the European Union has sought to re-inscribe a European identity via foreign and security policy making. ${ }^{39}$ Following David Campbell's re-theorisation of foreign policy as 'boundary-producing practices central to the production and reproduction of the identity in whose name is operates ${ }^{40}$, it could be argued that the European Union's foreign policy towards its southern neighbours (i.e. the Euro-Mediterranean partnership scheme) has served to make the latter foreign.

Indeed, the European Union's differentiated approach to security in the eastern and southern peripheries that characterised the 1990s could be interpreted as pointing to a shift in the EU discourse towards civilisational geopolitics. In the EU discourse, when the issue of the membership of the former Warsaw Pact countries is discussed, they are presented as 'returning to Europe', whereas Morocco's application for membership (1986) was rejected in 
no uncertain terms (without extending any alternative offers). Iver Neumann contrasts the rejection of Morroco's candidacy by the European Union with the integration of the German Democratic Republic. He finds it striking that the latter decision did not go through a process of referendum or even the approval of EU member states. Such practices of the European Union have not only helped to shape European identity by identifying who is or is not European, as Neumann emphasises, ${ }^{41}$ but also hinted at a return to civilisational geopolitics.

A similar language of cultural symbols was used by some EU policy makers in discussing Turkey's application for membership during the 1990s. For example, Wilfred Martens, a prominent German Christian Democrat, pronounced in 1997 that 'the EU is in the process of building a civilisation in which Turkey has no place'. ${ }^{42}$ More recently, the German conservative party CSU (Christian-Social Union of Bavaria) declared that 'the accession of a country that does not share the same religious or dominant values as the EU is "unimaginable" ${ }^{43}$ Although many prominent EU politicians distanced themselves from such remarks, some others chose not to. In the run up to the Copenhagen Summit, the opposition CDU-CSU coalition warned the government against giving 'false hopes' to Turkey at Copenhagen. Reporting on the developments, the EUobserver commented that 'even the moderate Christian Democrats, too embarrassed to use the "religious" argument, are referring to Turkey's backward economy' ${ }^{44}$ In the latter half of the 1990s, when Turkey's membership was not on the horizon, the sceptics wondered aloud as to

whether a semi-developed Islamic country could in fact be regarded as European - the boundaries to the New Europe had to be set somewhere, after all - and also whether post-Cold War Turkey's strategic significance was now so compelling. ${ }^{45}$

This was indeed what Turkish policy makers, as well as others in Turkey, asked themselves during the 1990s. What follows is an analysis of geopolitical imaginations of various actors in Turkey as reflected in their reactions to EU policies during the 1990s. ${ }^{46}$ The article will turn in the conclusion to look at Turkey-EU relations in the post-Helsinki era.

\section{Turkey between Europe and the Mediterranean}

The 1990s turned out to be a period of 'ontological insecurity' for Turkish policy makers who questioned Turkey's identity and its geographical location. ${ }^{47}$ This ambivalence is rooted in a discrepancy between Turkish policy makers' 'preferred geopolitical location' for Turkey (Turkey in Europe) and the 'position accorded to Turkey' in EU policy makers' discourse (Turkey in 'non-Europe', such as the Mediterranean or the Middle East). As David 
Newman has argued, 'the fact that the position accorded the state does not necessarily coincide with the preferred geopolitical location of the state, as reflected in its geopolitical imagination(s), may often be the cause for conflict and tension within the global system' ${ }^{48}$ The discrepancy between Turkish policy makers' 'preferred geopolitical location' and the one accorded to Turkey by their EU counterparts became a source of contention between the European Union and Turkey during the 1990s. ${ }^{49}$ Indeed, the European Union's ambivalence regarding the issue of Turkey's membership was viewed by some in Turkey as a rejection of Turkey's 'civilisational commitment' to the West - a commitment that has its roots in Kemal Atatürk's foreign and domestic policies. ${ }^{50}$

\section{Turkey's 'European Ideal'}

The strained dialogue on Turkey's geopolitical image and identity that characterised the 1990s was not new but could be traced back to the debates on the identity of the Ottoman Empire. For, while the Ottoman Empire could be considered a European state, at the same time it was not. When considering the place of the Ottoman Turks within an expanding international society, Thomas Naff concluded that 'even though a significant portion of the Empire was based in Europe, it could not be said to have been of Europe'.$^{51}$ John Agnew concurs: In the late eighteenth and early nineteenth century the 'otherness of Turks' had served as a 'fundamental barrier to their participation in a civilisational geopolitics that drew hard lines around its European homeland' ${ }^{52}$ Having said that, even during those times when the Ottomans were represented as 'Europe's significant (constitutive) other, they nevertheless were the 'sick man of Europe' and not Asia. ${ }^{53}$

Viewed from the inside, the ambivalence regarding Turkey's geopolitical location and civilisational identity was a topic for intense debates between the 'Westernisers', 'Islamists' and 'Turkists' during the later years of the Ottoman Empire. With the founding of the republic in 1923, this debate was resolved in favour of Westernisation in that Turkish policy makers' vocation has been one of locating Turkey firmly in the West. ${ }^{54}$ In Atatürk's lifetime, this vocation manifested itself in domestic reforms whilst a strictly 'realistic' policy of minimum involvement in disputes was pursued in the external realm. Realistic as it was, Kemalist foreign policy sought after one 'ideal': making Turkey a fullfledged member of the community of Western European states on an equal basis. ${ }^{55}$

Following Atatürk's death in 1938, a policy of minimum involvement in international disputes no longer seemed feasible given the international environment. Accordingly, during and in the aftermath of the Second World War Turkish policy makers sought to establish alliances with European powers. The Cold War and the prevalence of ideological geopolitics helped Turkish 
policy makers in this task. As the Cold War geopolitical imagination was centred around two alternative models of political-economic organisation, the East and the West, Turkey located itself in the West by virtue of its proWestern orientation and membership of European institutions.

In this context, membership in the North Atlantic Treaty Organisation (NATO) was viewed by Turkish policy makers as not only ending Turkey's anxieties caused by the Soviet Union's post-war demands (on its eastern provinces and the control of the straits) but also bringing Turkey into the European security system as a 'fully recognised European state'. ${ }^{56}$ Metin Tamkoç's comment that NATO membership 'secured formal acceptance of Turkey into what was then known as the "Western-Christian-Democratic family of European nations" which hitherto had kept the door shut to the Muslim Turks of the Middle East ${ }^{57}$ captures well this idealist dimension to Turkish foreign policy. Thus, in the immediate aftermath of the Second World War, becoming a NATO member emblemised the ideal of belonging to the community of Western European states. ${ }^{58}$

The roles Turkey played in European institutions have served as occasions on which Turkish policy makers articulated and defined Turkey's Western and/or European identity as well as maintaining its security needs and interests. During the Cold War, Turkish policy makers were enthusiastic participants in European institutions, membership in which was viewed as evidence of Turkey's claim to belong to the Western civilisation. Writing in 1977, Ismail Soysal, then Turkey's ambassador to Buenos Aires, maintained that 'the Turkish nation's Islamic creed cannot bar Turkey from taking its place within the community of nations who adhere to Western civilisation provided that it adequately conforms to the requirements of that civilisation' ${ }^{59}$

Soysal's words that located Turkey firmly in the West could also be viewed as an instance of Turkish foreign policy making as a boundaryproducing practice, for they served to (re)inscribe the boundary between Western and Islamic civilisations. Turkish policy makers were adamant in their choice of location for Turkey in the West, notwithstanding the pull of their Islamic creed toward non-West. Similarly, nowadays, when Turkish policy makers react to their EU counterparts' perceived unwillingness to allow Turkey into the European Union, they simultaneously signal their own unwillingness to see Turkey located in a non-Western geographical locale such as the Mediterranean or the Middle East.

Soysal's message was also intended for domestic consumption. He was reminding a domestic audience of the need to conform to the standards of the Western civilisation. Soysal wrote:

The more advanced and more lasting influence of Western civilisation on Turkish foreign policy has been the European Economic Community 
which is composed of nations that share the same system of values and that strive for eventual full political integration. Since 1963 when Turkey signed its Treaty of Association with the European Community Turkey has begun a new period of 'harmony of civilisations'. In the future if we are sincere in our association and our full membership we should have no qualms about Western civilisation and democratic order. We believe this is a way of no return for Turkey. ${ }^{60}$

Other authors voiced similar views on Turkey's geographical location, and the relationship between that location, Turkey's civilisational identity and domestic politics in an attempt to evoke and realise a domestic self that was 'European':

While some countries which were geographically situated in Europe could not be admitted to the membership of the Council of Europe or were later dismissed from it because they did not have a democratic system Turkey has been able to maintain its place. Turkey is considered European because it believes in the democratic system of government, implements it earnestly and keeps its pace with the contemporary civilisation. As the only Islamic European country, it will keep its European identity so long as it fulfils the requirements of our present civilisation. ${ }^{61}$

In time, as the European Coal and Steel Community broadened its span and activities to transform itself into the European Community/European Union, joining the EU became the new ideal.

When the Cold War ended, those who sincerely believed in the EC/EU route being a 'way of no return' for Turkey were faced with a major problem. As the European Union sought to relocate itself in the evolving map of world politics, Turkish policy-makers discovered to their dismay that the place accorded to Turkey might not fall within the boundaries of 'new Europe'. Thus, in the absence of the (communist) 'East' - the 'other' against which Turkey substantiated its claim to membership of the 'West' and/or 'Europe'the long-standing discrepancy between Turkish policy-makers' preferred geopolitical location and that accorded by their European counterparts forced itself unto the post-Cold War agenda of Turkish policy-makers. During the 1990s, as the Westernising elite's 'hand' was weakened as a result of the ambivalent attitude of their EU counterparts, the debate on Turkey's geopolitical location and identity was re-opened.

Accordingly, EU policy makers' aforementioned scepticism regarding Turkey's place in the European Union has been viewed by many in Turkey as a challenge to its Western and/or European identity. In the immediate aftermath of the declaration of Agenda 2000, ${ }^{63}$ which did not put Turkey on the list of candidate countries, many in Turkey felt betrayed by their EU counterparts. 
This feeling of betrayal is captured nowhere better than the website of the Turkish Ministry of Foreign Affairs, which seeks to remind readers that 'having played an active role in the demise of the Soviet bloc, it was only natural for Turkey to aspire for inclusion in the new European architecture which it helped to build' ${ }^{64}$ In response to this perceived betrayal of their EU counterparts ${ }^{65}$ Turkey's policy makers sought to play the security card, which had previously secured Turkey's membership in many European institutions during the Cold War. What seemed to have escaped Turkey's policy makers was the extent to which the European Union's conception and practices of security were transformed throughout the years and that Turkey and its EU counterparts grew increasingly apart from each other. During the Cold War, the European Union made use of the security umbrella provided by NATO and adopted a unique approach to security building by putting a broader range of issues on the agenda (such as economic, environmental and human rights issues) without labelling them as security issues. This enabled EU policy makers to find a common ground in the solution of a broad range of problems without getting entangled in East-West confrontation.

The differences between Turkey and the European Union are not limited to the stress put by EU policy makers on the non-military dimensions of security and the use of non-military instruments such as soft governance and common security practices. Perhaps more significantly, this unique approach to security building in the European Union began to constitute its own insecurities in the form of soft security threats after the end of the Cold War. This has meant the labelling of a range of issues (such as South-North migration and drug trafficking) as security problems and the launch of projects such as the EuroMediterranean partnership. Eventually, the issue of Turkey's membership became more of a challenge for the European Union. In the post-Cold War context where threats to security are perceived to take the form of soft security threats, Turkey's massive population emerges as one of the sources of this problem. As will be argued below, there is as yet little awareness among Turkey's policy makers that this transformation in the security conceptualisation and practice of the EU may mean that security relations may not serve as the strongest of ties that bind Turkey to Europe, so long as this gap in security thinking and practices is not bridged. ${ }^{66}$

\section{Turkey's 'Security Card'}

Even though some among the Turkish policy making elite may have had their doubts regarding Turkey's place in Europe in terms of civilisational identity, a significant part of their claim to belong to Europe rested on the role Turkey played in the European security architecture during the Cold War. In the latter half of the 1990s, as the European Union sought to develop its Common European Security and Defence Policy (CESDP), Turkish policy makers 
found Turkey being increasingly excluded from the EU's evolving security policies. This feeling of betrayal was coupled with a sense of shock when the aforementioned challenge to Turkey's Europeanness was extended to the realm of security. General Çevik Bir, then deputy chief of Turkish General Staff, gave voice to Turkish policy makers' concerns when he said: 'Even as the importance of collective defence and the transatlantic link are being emphasised within NATO, simultaneously contradictory arguments are also being advanced, which can only be described as "Europe is for the Europeans". ${ }^{67}$ This seemingly growing gap between the security perceptions and policies of Turkey and the European Union is viewed by some Turkish observers as 'paradoxical' in that

although Turkey fully participates in the European Security Architecture, even here it encounters problems because it is excluded from the EU's evolving defence arm - CESDP (Common European Security and Defence Policy) - which is part of this architecture. This is an interesting point because security was one of the strong links tying Turkey to Europe and vice versa. ${ }^{68}$

Yet what is often forgotten is that Turkish policy makers and their European counterparts do not see eye to eye when they discuss issues of security in Europe. As noted above, they conceive security differently. ${ }^{69}$

Turkey participated in the maintenance of security in Europe during the Cold War by virtue of its strategically significant geographical location, the size of its army and the pro-Western orientation of the Turkish regime that helped bolster the identity of the West. ${ }^{70}$ However, as the Soviet threat to Eastern Europe lost its imminence, and the European Community transformed itself to a 'security community' ${ }^{71}$ Turkey's contribution to security building in Europe became less significant in the eyes of EU policy makers. Although the aforementioned gap between the security perceptions and interests of Turkey and its Western European allies were kept under the lid until the late 1980s, the dissolution of the Soviet Union (1991) brought it out into the open.

Over the years, the European Union focused on managing non-military dimensions of security whereas NATO - where Turkey played its role - took care of the military dimension. With the end of the Cold War and the decline in the significance of NATO for security building in Western Europe, Turkey's significance also seemed to decline. For, when viewed from an EU perspective, Turkey's location in a 'rough neighbourhood"72 - what Turkish policy makers represent as a significant asset - might become a source of instability (i.e. burden). Furthermore, during the Cold War, the European Union adopted a comprehensive conception of security and increasingly relied on non-military instruments whereas Turkey, still surrounded by conventional threats to its security, hesitated to make similar changes in its thinking and practices. 
The persistence of this gap despite the European Union's increasing interest in military dimensions of security ${ }^{73}$ was viewed as surprising by some in Turkey who expected a closer EU-Turkey relationship to evolve now that the EU seemed to need Turkey's military goods for crisis management purposes. Such arguments are based on the understanding that the European Union is on its way to become a military power as opposed to the civilian power it was during the Cold War years. Accordingly, observers in Turkey expect that the normalisation of the European Union would result in enhanced EU interest in Turkey's strategic geopolitical location. General Bir, for one, believes that "the new risks and challenges that could affect the whole Western world have transformed Turkey from a "flank" to a "front state". Turkey is one of the few Western countries whose importance has increased in the post-Cold War period. ${ }^{74}$ Minister of Defence Hikmet Sami Türk concurs:

Geographic destiny placed Turkey in the virtual epicentre of a 'Bermuda Triangle' of post-Cold War volatility and uncertainty, with the Balkans, the Caucasus, and the Middle East encircling us. Rather than isolating ourselves from the pressing conflicts at our doorstep, Turkey decided to assume a pivotal role in promoting regional peace, stability and cooperation in contributing to vital efforts to end human suffering and conflict. ${ }^{75}$

What Turkish policy makers often seem to forget is the persistence of the aforementioned discrepancy between their preferred geopolitical location for Turkey and that of their EU counterparts and, equally significantly, the differences between their approaches to security. The latter is likely to become a contentious issue as Turkey moves further along on the path to EU membership. In the aftermath of the Copenhagen Summit, EU policy makers put the issue of the 'definitive separation of civil and military competencies in exercising power' on the agenda of EU-Turkey relations. ${ }^{76}$ The privileged position traditionally accorded to the military in Turkey ${ }^{77}$ in the making of foreign and security policies could become a bone of contention in Turkey-EU relations in the near future. Space does not permit further discussion of TurkeyEU security relations and the role of the military in foreign and security policymaking. ${ }^{78}$ Suffice it to note here that during the 1990s, Turkey not only failed to adopt broad conceptions of security, but it also experienced a securitisation of its foreign policy whereby certain issues were pulled out of the realm of open debate and discussion by way of declaring them as national security issues. ${ }^{79}$

\section{(Re)locating Turkey-'Not in the Mediterranean!'}

In reaction to this perceived betrayal of their EU counterparts, Turkish policy makers sought to de-emphasise Turkey's European identity and re-locate Turkey in the Black Sea, and Central Asia (the so-called 'Turkic world'). 
Hence the aforementioned struggle for (re)locating Turkey in the post-Cold War geographical terrain of world politics. A discussion of Turkey's many geographical positions and identities is beyond the confines of this article. Suffice it to note here that the diversity in Turkey's geopolitical imagining and positioning that was already apparent during the Cold War became only more apparent in its wake. Traditionally, this diversity has been presented as an asset by Turkey's policy makers. The website of the Turkish Ministry of Foreign Affairs describes Turkey's geographical position as follows:

[Turkey] lies at the 'crossroads' where two continents, Europe and Asia, meet, and also where cultures and civilisations come together. This unique position gives her European, Balkan, Mediterranean, Middle Eastern, Caucasian and Asian identities all at the same time. ${ }^{80}$

A retired general of the Turkish armed forces (who is also the author of many books on Turkey's geopolitics) ${ }^{81}$ describes Turkey's location in more stark terms:

Turkey constitutes the hinge of the world island that is made up of three continents. It is both the lock and the key to this hinge. It connects the Mediterranean and the Black Sea... It brings together and keeps apart the Balkans, Caucasus and the Middle East. ${ }^{82}$

This sense of being at the crossroads of two (or three) continents has had diverse implications for Turkey's foreign and security policies as viewed in the discourses of Turkey's policy makers. Turkey's geographical position is presented as offering unique opportunities (such as the potential to play the role of a bridge between different civilisations) whilst constituting unique vulnerabilities (such as claims on Turkey's resources and territory, heterogeneous population make-up, and historical disputes with neighbouring countries which have diverse strategic cultures). What seems common to all such representations is the emphasis put on the diversity in Turkey's geopolitical positioning as reinforcing Turkey's claim to a European identity: 'Turkey is not searching for alternatives to Europe. Our European policies have always been complementary to the other dimensions of our foreign policy and vice versa', maintained Özdem Sanberk, then Turkey's ambassador to London. ${ }^{83}$

Ole Wæver has insight into the reason why Turkish policy makers are so wary of over-emphasising the non-European dimensions of Turkey's identity. The reason, argues Waever, is that 'in accordance with traditional European prejudices, the more Turkey is seen to turn towards the East, the less it will be deemed "European", ${ }^{84}$ Indeed, over the years, Turkey sought to use the BSEC (Black Sea Economic Cooperation) initiative and its links with Central Asian countries to increase its value regarding the economic ambitions and security concerns of the European Union and not as an alternative to EU 
membership. In other words, such alternative geopolitical images were almost always used to bolster Turkey's geopolitical location in Europe by enhancing its value for EU (or US) interests in the aforementioned regions. There is also some evidence that the United States and to a lesser extent the European Union are interested in investing in Turkey's future as Central Asia's 'gateway to the West'. ${ }^{85}$

During this period, the Mediterranean dimension of Turkey's identity was remarkable for its absence from the discussions on geopolitical identities of Turkey. In the eyes of Turkish policy makers, it is viewed as acceptable to locate Turkey in the Mediterranean so long as this representation is considered alongside Turkey's other geopolitical locations including Europe, the Middle East, the Black Sea and the Turkic World. See, for instance, the following excerpt from an article by an official of the Turkish Ministry of Foreign Affairs:

Turkey's international role, in the current stage of world developments, may be defined as the sum of the parts she plays in the multiple context of the evolving equation in Europe, the Balkans, the Eastern Mediterranean, the Black Sea and Transcaucasus regions, as well as the Trans Caspian area. ${ }^{86}$

What is interesting is that even when the Mediterranean is mentioned, it is not conceived as a totality (as it is by the European Union). It is the Eastern Mediterranean that is referred to: the part of the Mediterranean that NATO is interested in and where Turkey has a clearly defined role as part of a European security organisation. When the Mediterranean is presented as an alternative to Europe, Turkish policy makers do not wish to see Turkey located in the Mediterranean. The EU policy makers' aforementioned construction of the Mediterranean as non-Europe has certainly not helped in alleviating the fears of Turkish policy makers who think that Turkey is offered a place in EMP as an alternative to joining the European Union, and that it is being located geographically in the peripheries and not in Europe.

Notwithstanding Turkish policy makers' misgiving regarding the EuroMediterranean Partnership scheme, Turkey did participate in the negotiations and sign under the Barcelona treaty - but only as a reluctant partner. Indeed, when compared with their enthusiasm regarding the BSEC project, Turkish policy-makers' interest in the Euro-Mediterranean Partnership scheme has been rather dim. ${ }^{87}$ An official of the European Commission in Turkey even felt the need to reassure Turkey's policy makers that 'active participation in the Euro-Mediterranean Partnership does not mean stepping out of the process of full membership to the European Union. Turkey should overcome its scepticism and take part in the process of economic integration of the Mediterranean'. ${ }^{88}$

Although it is possible to interpret the Turkish policy makers' stance toward the Euro-Mediterranean Partnership scheme as one of 'indifference' ${ }^{89}$ 
the argument here is that their attitude could be labelled as anything but indifference. Indifference implies a passive stance; it involves a lack of interest. However, Turkish policy makers have been active in their promotion of Turkey's other identities (in particular that of BSEC and the Turkic World) but not that of the Mediterranean. Thus, Turkish policy makers are wary of providing substance to EU policy makers' efforts to locate Turkey in the Mediterranean.

Furthermore, there is some evidence that the Turkish foreign policy elite have resented the European Union's categorisation of Turkey with other nonEU Mediterranean countries. Resentment is more active an attitude than indifference - the former involves bitterness and even anger. Turkish policy makers' perception is that the Euro-Mediterranean Partnership scheme 'reduces the status of Turkey in the EU into a neighbouring country, ${ }^{90}$ and that Turkey cannot be put in the same 'Mediterranean' basket as with the Maghreb and Mashreq countries that do not aspire to join the European Union. Accordingly, it could be argued that Turkish policy makers view the Mediterranean from the lens of Turkey's European vocation. Thus, they resent being invited to sit at the other side of the table together with other non-EU Mediterranean countries. ${ }^{91}$ Turkish policy makers also consider the European Union's mid-1990s attempts to transfer funds to Turkey through the EMP (funds that are held up by the Greek veto) not as a goodwill gesture, but as 'political behaviour that proves the EU's exclusionary policy toward Turkey' ${ }^{92}$ Such policy, in turn, is symptomatic of a lack of self-reflection on the part of Turkey's policy makers. Whilst criticising their EU counterparts for erecting walls between Turkey and Europe, their own foreign policy discourse on the issue of Euro-Mediterranean partnership has served as a boundaryproducing practice in that, in seeking to locate Turkey in Europe, they distanced themselves from the Mediterranean. This, in turn, is not promising in terms of Turkey's claim to contribute to harmony between civilisations as a future member of the EU.

\section{Conclusion}

Turkey-EU relations have been far from unchanging in the way the logic of a discourse based on civilisational differences would imply. The European Union's 1999 decision to recognise Turkey as a candidate country in itself could be viewed as negating the argument that 'the Muslim world, including Turkey, is appearing once again as the counterpart to Europe, as its "relevant other", ${ }^{93}$ For, although the Turkish other has been significant in the making of Europe, the other(s) of Europe has changed throughout history.

Since the 1999 decision of the European Union to recognise Turkey's candidacy, Turkey-EU relations have taken a different turn. The economic crisis 
of 2000 gave rise to a feeling of emergency, which enabled the pro-EU circles in Turkey to push for not only financial-economic reforms (also demanded by the IMF) but also political ones required by EU conditionality. During this period Turkey's constitution was amended. Of the 34 articles that have recently been amended, 22 also coincide with the wishes of the European Union. The most recent changes (made in the summer of 2002) include improving human rights, strengthening the rule of law and restructuring of democratic institutions. ${ }^{94}$ These are expected to be followed by complementary legislative and administrative measures to ensure their implementation. Furthermore, at the Copenhagen Summit, the disagreements between Turkey and its EU counterparts on the issue of European security and defence policy were overcome. However, the issue of the discrepancies between the security conceptions and practices of the EU remains.

One question that still demands an answer is whether EU policy makers are likely to succeed in avoiding a drift towards the civilisational geopolitics that coloured their post-Cold War security discourse. As Barry Buzan and Thomas Diez have argued, the talk about who is "wholly "in" or "not in" has narrowed political visions in an unhealthy way, and runs counter to the EU's increasingly "postmodern" character'. ${ }^{95}$ Giscard d'Estaing's intervention in the EU debate on Turkey's membership and the debate in Germany has shown that an understanding of geography shaped by civilisational geopolitics continues to influence the discourse of some in the European Union. ${ }^{96}$ This, in turn, might have repercussions for the European Union's Mediterranean policy. There already is an awareness of the broader impact EU-Turkey relations could make on the rest of the Muslim world. Making the case for Turkey's membership, the Economist recently noted:

An EU that is open to Turkey should send a message to the troubled Muslim world of today: the West does not consider Islam and democracy incompatible as long as Islam doesn't... Offering a provisional date for the start of negotiations is an historic chance for Europe but also for the Muslim world to show that their two great civilisations are not fated always to clash. ${ }^{97}$

Indeed, an improvement in Turkey-EU relations might enable the European Union to present itself to its southern periphery as a truly multi-cultural entity that is not anti-Muslim. Accordingly, it is possible to view the December 2004 date presented to Turkey at the Copenhagen summit as an attempt to give Turkey a 'strong signal' (thereby avoiding alienating Turkey and the rest of the Muslim world) while keeping the domestic opposition at bay. In the coming years, the challenge for those working for Turkey's membership would not only be that of fulfilling the EU criteria but also that of overcoming the prejudices of those whose discourse on Turkey's membership hint at a possible 
return of civilisational geopolitics. This would not be an easy task given the ways in which Turkish foreign policy during the republican period was utilised to help evoke and realise a domestic self that is European and Western - an identity that was maintained against non-European and non-Western others. ${ }^{98}$

\section{ACKNOWLEDGEMENTS}

This is a revised version of a paper presented at Workshop 14: Geopolitical Images and Discourses: Europe, the Mediterranean and the Middle East, organised as a part of the Third Mediterranean Social and Political Research Meeting, Florence, 20-24 March 2002, Mediterranean Programme, Robert Schuman Centre for Advanced Studies, European University Institute. The author would like to thank the organisers of the workshop, David Newman and Susanne Peters, the workshop participants and three referees the journal for their comments and criticisms.

\section{NOTES}

1. J. Agnew, Geopolitics: Revisioning World Politics (London: Routledge 1998) p.119.

2. I.O. Lesser, Bridge or Barrier? Turkey and the West after the Cold War (Santa Monica, CA: Rand 1992); D. Sezer, 'Turkey and the European Idea', NATO's Sixteen Nations 4 (1993) pp.82-7.

3. The expression 'European Union' or 'EU' will be used throughout the essay to refer to the organisation of European states (EEC and EC) before the adoption of the current title in 1992.

4. T. Garton Ash, 'The European Orchestra', The New York Review of Books, 17 May 2001, p.60.

5. See, for example, Agnew (note 1); J. Agnew and S. Corbridge, Mastering Space: Hegemony, Territory and International Political Economy (New York: Routledge 1995); S. Dalby, 'Critical Geopolitics: Discourse, Difference and Dissent', Environment and Planning D: Society and Space 9 (1991) pp.261-83; D. Newman (ed.), Boundaries, Territory and Postmodernity (London: Frank Cass 1999); G. Ó Tuathail and S. Dalby (eds), Rethinking Geopolitics (London: Routledge 1998); G. Ó Tuathail, S. Dalby and P. Routledge (eds), The Geopolitics Reader (London: Routledge 1998).

6. Critical theories of International Relations include feminism, post-structuralism, Frankfurt School Critical Theory, constructivism as well as historical sociology. This article draws upon the following literature (in alphabetical order): K. Booth, 'Security and Emancipation', Review of International Studies 17 (1991) 313-26; K. Booth (ed.), Security, Community and Emancipation: Critical Security Studies in World Politics (Boulder, CO: Lynne Rienner forthcoming); D. Campbell, Writing Security: United States Foreign Policy and the Politics of Identity (Manchester: Manchester University Press, 1992); K. Krause and M. Williams (eds), Critical Security Studies: Concepts and Cases (London: UCL Press 1997); B. McSweeney, Security, Identity and Interests: A Sociology of International Relations (Cambridge: Cambridge University Press 1999); I. Neumann, The Uses of the Other: 'The East' in European Identity Formation (Manchester: Manchester University Press 1999); J.A. Tickner, Gender in International Relations: Perspectives on Achieving Global Security (New York: Columbia University Press 1992); O. Wæver, 'Securitization and Desecuritization', in R.D. Lipschutz (ed.), On Security (New York: Columbia University Press 1990) pp.46-86; J. Weldes, M. Laffey, H. Gusterson and R. Duvall (eds), Cultures of Insecurity: States, Communities, and the Production of Danger (Minneapolis, MN: University of Minnesota Press 1999).

7. Agnew (note 1), pp.86-124. Agnew and Corbridge (note 5), pp.46-77 also adopt this periodisation.

8. This is not to suggest that the prevalence of a single geopolitical discourse is considered as desirable.

9. See, for example, Z. Öniş, 'Turkey, Europe, and Paradoxes of Identity: Perspectives on the International Context of Democratisation', Mediterranean Quarterly 10/3 (Summer 1999) pp.107-36; G. Aybet and M. Müftüler-Baç, 'Transformations in Security and Identity After the 
Cold War: Turkey's Problematic Relationship with Europe', International Journal 55/4 (Autumn 2000) pp.567-82.

10. O. Öymen, 'Turkish Foreign Policy: Current Challenges' PolicyWatch 238 (1997). See <http://www.washingtoninstitute.org/watch/Policywatch/policywatch1997/238.htm> (accessed 11 December 2001).

11. Presidency conclusions of the European Union summits are available at <http:// www.europa.eu.int/council/off/conclu/index.htm> (accessed 20 December 2002).

12. 'Gül'den değerlendirme: "Artık biz AB'ye baskı yapıyoruz"' (Gül's Comment: Now We are Putting Pressure on the EU), Milliyet, 14 December 2002.

13. Mümtaz Soysal, 'Caritas', Cumhuriyet, 16 December 2002.

14. Erol Manisalı, 'Oyalanmaktan Kimler Hoşlanır...' (Who enjoys being lulled ...), Cumhuriyet, 16 December 2002.

15. 'Giscard's Gaffe', Financial Times, 11 November 2002, p.12.

16. Campbell (note 6), p.75.

17. Although it could be argued that 'Islam' in Turkey has been different from 'Islam' in the Arab world, it is also worth noting that there are differences within the Arab world itself.

18. McSweeney (note 6), p.7.

19. See, for example, J. Baylis, "European Security Between the "Logic of Anarchy" and the "Logic of Community", , in C. Hodge (ed.), Redefining European Security (New York: Garland 1999) p.19; A. Hyde-Price, 'The Antinomies of European Security: Dual Enlargement and the Reshaping of European Order', Contemporary Security Policy 21/3 (2000) p.149.

20. T. Hentch, Hayali Doğu: Batı'nın Akdenizli Doğuya Politik Baklşı [Imagined East: The West's Political View of the Mediterranean East], translated by Aysel Bora (İstanbul: Metis 1996).

21. The terms 'East' and 'West' gained new meanings during the Cold War when they were used to refer to the two blocs headed by the Soviet Union and the United States.

22. K. Wigen and M. Lewis, The Myth of Continents: A Critique of Metageography (Berkeley, CA: University of California Press 1997) p.36.

23. J. Attali, 1492, translated by Mehmet Ali Kılıçbay (İstanbul: Yapı Kredi Yayınları, 1992).

24. F. Braudel, Akdeniz ve Akdeniz Dünyasi, translated by Mehmet Ali K1lıçbay [The Mediterranean and the Mediterranean World] (İstanbul: Eren 1990).

25. P.E. Salem, 'Arab Political Currents, Arab-European Relations and Mediterraneanism', in L. Guazzone (ed.), The Middle East in Global Change: The Politics and Economics of Interdependence versus Fragmentation (London: Macmillan 1997) pp.23-42.

26. Ibid. p.38.

27. Ibid.

28. M. El-Sayed Selim, 'Mediterraneanism: A New Dimension in Egypt's Foreign Policy', Kurasat Istratijiya [Strategic Papers of the Al-Ahram Center for Political and Strategic Studies] 4/27 (1997). See <http://www.acpss.org/ekuras/ek27a.html> (accessed 19 September 1999).

29. Salem (note 25$)$ p.38.

30. See, for example, O. Wæver, 'Visions of Conflict: Conflicts of Vision', in O. Wæver, P. Lemaitre and E. Tromer (eds), European Polyphony: Perspectives Beyond East-West Dialogue (New York: St Martin's Press 1989) pp.283-325; K. Booth and N. J. Wheeler, 'Contending Philosophies About Security in Europe', in C. McInnes (ed.), Strategy and Security in the New Europe (London: Routledge, 1992) pp.3-36; P. Bilgin, 'Whose Middle East? Geopolitical Inventions and Practices of Security', International Relations 18/1 (2004) pp.17-33.

31. P. Bilgin, 'Inventing Middle Easts? The Making of Regions Through Security Discourses', in B.U. Utvik and K. S. Vikør (eds), The Middle East in a Globalized World (Bergen: Nordic Society for Middle Eastern Studies 2000) pp.10-37.

32. Neumann (note 6) p.115.

33. H. Jawad The Euro-Arab Dialogue: A Study in Collective Diplomacy (Reading: Ithaca 1992).

34. This, however, should not be taken to suggest that the European Union has adopted a single common approach or that EU policymakers are speaking with one voice regarding Mediterranean issues. On the contrary, there are significant differences among EU member states.

35. D. Bigo, 'When Two Become One: Internal and External and Securitizations in Europe', in M. Kelstrup and M. C. Williams (eds), International Relations Theory and the Politics of European Integration: Power, Security and Community (London: Routledge 2000) p.182. 
36. G. Salamé, 'Torn between the Atlantic and the Mediterranean: Europe and the Middle East in the post Cold War era', Middle East Journal 48/2 (1994) pp.226-49.

37. F. Heisbourg, 'The United States, Europe, and the Military Force Projection', in R.D. Blackwill and M. Stürmer (eds), Allies Divided: Transatlantic Policies for the Greater Middle East (Cambridge, MA: MIT Press 1997) p.284.

38. Ibid. p.285.

39. Michelle Pace, 'The Ugly Duckling of Europe: The Mediterranean in the Foreign Policy of the European Union', Journal of European Area Studies 10/2 (2002) pp.189-209.

40. Campbell (note 6) p.75.

41. Iver Neumann, ‘Avrupa Kimliği, AB genişlemesi ve Entegrasyon/Dışlama Bağlantısı' [European Identity, EU Expansion and Integration/Exclusion], Avrasya Dosyast 5/4 (1999) pp.9-10.

42. 'Turkey and Europe: Just not our Sort', Economist (1 March 1997) p.30. This is not to argue that the EU should expand to integrate all its neighbours. EU members surely have the right to decide who is in and who is out. Yet, what is significant is that EU discourse is full of cultural and civilisational references.

43. 'France and Germany Unify Over Turkey', EUobserver, <http://www.euobserver.com/ index.pthtml?aid=8639> (accessed 19.12.2002).

44. Ibid.

45. W. Park, 'Turkey's European Union Candidacy: From Luxembourg to Helsinki - to Ankara?', Mediterranean Politics 5/3 (2000) p.34.

46. The texts analysed here are taken from two sources. One is the Ankara-based quarterly journal Dış Politika/Foreign Policy, which is published by an independent think-tank, the Foreign Policy Institute. This journal is the oldest of its kind in Turkey and publishes the speeches of (as well as articles by) the foreign policy elite in Turkey. The journal is published in both English and Turkish. The second source is the website of the Washington-based Institute of Near East Policy, that publishes the speeches of various Turkish foreign and security intellectuals that were delivered at the Institute. Both sources proved invaluable in presenting Turkish foreign and security intellectuals' representations of Turkey's geopolitical location.

47. Sezer (note 2).

48. D. Newman, 'Geopolitics Renaissant: Territory, Sovereignty and the World Political Map', in idem, Boundaries (note 5) pp.1-16.

49. For a recent overview of Turkey-EU relations, see Meltem Müftüler-Baç, Türkiye ve AB: Soğuk Savaş Sonrasi Illişkiler [Turkey and the EU: post-Cold War Relations] (İstanbul: Alfa 2001).

50. B. Kuniholm, 'Turkey's Accession to the European Union: Differences in European and US Attitudes, and Challenges for Turkey', Turkish Studies 2/1 (2001) p.27.

51. T. Naff, 'The Ottoman Empire and the European State System', in Hedley Bull and Adam Watson (eds), The Expansion of International Society (Oxford: Clarendon 1985) p.143, cited in Neumann (note 6) p.40.

52. Agnew (note 1) p.94.

53. Neumann (note 6) pp.55-9.

54. The debate was re-opened in the 1990s. See N. Bilgin (ed.), Cumhuriyet, Demokrasi ve Kimlik [The Republic, Democracy and Identity] (İstanbul: Bağlam Yayıncılık 1997) for a collection of select essays.

55. Aptülahat Akşin, Atatürk'ün Dış Politika İlkeleri ve Diplomasisi [Atatürk's Foreign Policy Principles and Diplomacy] (Ankara: Türk Tarih Kurumu 1991).

56. Y.Y. Kurat, 'Turkey's Entry into the North Atlantic Treaty Organisation', Dış Politika/Foreign Policy 10/3-4 (1984) p.77.

57. M. Tamkoç, 'The Impact of the Truman Doctrine on the National Security Interests of Turkey', Diş Politika/Foreign Policy 6/3-4 (1977) p.30.

58. D. Vardar, 'Türkiye'nin Bati Avrupa Kurumlarına Girişi ve Kamuoyu', [Turkey's Entry into Western European Institutions and Public Opinion] in F. Sönmezoğlu (ed.), Türk Dış Politikasının Analizi [Analysis of Turkish Foreign Policy] (İstanbul: Der Yayınları 1994) pp.373-82.

59. İ. Soysal, 'The Influence of the Concept of Western Civilisation on Turkish Foreign Policy', Dış Politika/Foreign Policy 6/3-4 (1977) p.3. 
60. Ibid., p.6.

61. An Observer, 'Multifaceted Foreign Policy As a New Approach', Dış Politika/Foreign Policy 6/3-4 (1977) p.13.

62. See Sezer (note 2); H. Kramer, A Changing Turkey: Challenges to Europe and the United States (Washington, DC: Brookings Institution Press 2001); İ.D. Dağı, Kimlik, Söylem ve Siyaset: Doğu-Bati Ayrımında Refah Partisi Geleneği [Identity, Discourse and Politics: Welfare Party Tradition at the East/West Juncture] (Ankara: Imge 1998); Erol Manisalı, Türkiye-Avrupa Birliği Illişkilerinde 'Sessiz Darbe' [The 'Silent Coup' in Turkey-EU Relations] (İstanbul: Derin Yayınları 2002).

63. Agenda 2000 was declared in 1999. See <http://www.europa.eu.int/comm/agenda2000/ index_en.htm> (accessed 26 November 2002).

64. 'Relations Between Turkey and the European Union.' See <http://www.mfa.gov.tr/grupa/ad/ adab/relations.html> (accessed 26 March 2001).

65. Having said that, it should also be noted that the European Union had its own reasons for hesitating to include Turkey in Agenda 2000. Some in Turkey now recognise that the decades that followed the 1980 military coup were lost not only in terms of Turkey-EU relations but also in terms of Turkey's domestic political development. These reasons include, among others, Turkey's human rights record, the dire state of the Turkish economy, and the role of the military in Turkish politics.

66. P. Bilgin, 'A Clash of Cultures? Differences Between Turkey and the European Union on Security', in Ali L. Karaosmanoğlu, (ed.), Turkey-EU Relations: Convergence and Divergence (forthcoming).

67. Ç. Bir, 'Turkey's Role in the New World Order', Strategic Forum 135 (1998). See <http:// www.ndu.edu/inss/strforum/forum135.html> (accessed 19 November 2001).

68. Aybet and Müftüler-Baç (note 9) p.569. Emphasis added.

69. The issue of human rights provides a striking example of these differences. See Bilgin (note $66)$.

70. for a discussion, see P. Bilgin, 'Turkey and the EU: Yesterday's Answers to Tomorrow's Security Problems?', in G.P. Herd and J. Huru (eds), EU Civilian Crisis Management (Surrey: Conflict Studies Research Centre, Royal Military Academy Sandhurst, 2001) pp.34-51.

71. 'Security community' is a concept developed by K. Deutsch; Karl W. Deutsch and Sidney Birrell, Political Community and the North Atlantic Area: International Organization in the Light of Historical Experience (Princeton, NJ: Princeton University Press 1957). Western Europe (or the European Union) is often viewed as close as it gets to a security community. See O. Wæver, 'Insecurity, Security and Asecurity in the West European Non-War Community', in E. Adler and M. Barnett (eds), Security Communities (Cambridge: Cambridge University Press 1998) pp.69-118.

72. Ş. Ergüvenç, 'Turkey's Security Perceptions', Perceptions 3 (June-August 1998) p.32.

73. S. Rynning, 'Providing Relief or Promoting Democracy? The European Union and Crisis Management', Security Dialogue 32/1 (2001) pp.87-101; François Heisbourg, 'Europe's Strategic Ambitions: The Limits of Ambiguity', Survival 42/2 (2000) pp.5-15.

74. Bir (note 67).

75. H.S. Türk, 'Turkish Defense Policy', speech delivered at the Washington Institute for Near East Policy, 3 March 1999. See <http://www.washingtoninstitute.org/media/samiturk.htm> (accessed 19 November 2001).

76. 'Outcome of the Copenhagen Summit', EUROPARL Press Service, <http:// www.europarl.eu.int/press/index_en.htm> (accessed 19 December 2002).

77. Ümit Cizre, 'Problems of Democratic Governance of Civil Military Relations in Turkey and the EU Enlargement Zone', European Journal of Political Research 43/1 (January 24) pp.107-25. Also see Ümit Cizre, 'The Anatomy of the Turkish Military's Political Autonomy', Comparative Politics 29/4 (2004) pp.151-65.

78. On the role of the military in security policy-making, see Ali L. Karaosmanoğlu, 'The Evolution of the National Security Culture and the Military in Turkey', Journal of International Affairs 54/1 (2000) pp.199-216. On the security dimension of Turkey-EU relations, see Bilgin, 'A Clash of Cultures? (note 66). On changes in Turkey's security discourse over the years, see 
Pinar Bilgin, 'Rethinking Turkey's Security Discourse: The Challenge of Globalisation', European Journal of Political Research (forthcoming) paper presented at the Annual Meeting of the American Political Science Association, Boston, MA, 29 August-1 September 2002.

79. Gencer Özcan, 'Doksanlarda Türkiye'nin Ulusal Güvenlik ve Dıß̧ Politikasında Askeri Yapının Artan Etkisi,' (The Increasing Influence of the Military Structure on Turkey's National Security and Foreign Policy during the Nineties) in En Uzun Onyll: Türkiye'nin Ulusal Güvenlik ve Dış Politika Gündeminde Doksanlı Ylllar (The Longest Decade: Turkey's National Security and Foreign Policy Agenda During the Nineties) (İstanbul: Boyut 1998) pp.67-100.

80. See <http://www.mfa.gov.tr/grupg/gb/default.htm> (accessed 1 December 2002).

81. Suat İlhan, Jeopolitik Duyarlılık [Geopolitical Vulnerability] (Ankara: Türk Tarih Kurumu 1989);Türkiye'nin ve Türk Dünyasının Jeopolitiği [The Geopolitics of Turkey and the Turkic World] (Ankara: Türk Kültürünü Araştırma Enstitüsü 1997); Türkiye'nin Jeopolitik Konumu ve Türk Dünyass [Turkey's Geopolitical Position and the Turkic World] (Ankara: AYK 1999); Avrupa Birliğine Neden Hayır: Jeopolitik Yaklaşim [Why 'No' to the European Union: A Geopolitical Perspective] (İstanbul: Ötüken 2000).

82. İlhan, Avrupa Birliğine Neden Hayır (note 81) p.34.

83. Ö. Sanberk, 'The Outlook for Relations between Turkey and the European Union after the Cardiff Summit', speech delivered at the Washington Institute for Near East Policy, 20 July 1998. See <http://www.washingtoninstitute.org/media/sanberk.htm> (accessed 11 December 2001).

84. O. Wæver, 'Europe's Three Empires: A Watsonian Interpretation and Post-Wall European Security', in Rick Fawn and Jeremy Larkins (eds), International Security After the Cold War (London: Macmillan 1996) p.237.

85. Ibid. p.238.

86. Ö. Orhun, 'Turkey, Norway and the US in the New European Security Context', Dış Politika/ Foreign Policy 21/1-2 (1997) p.7.

87. F. Tayfur, 'Turkish Foreign Policy Towards the Euro-Mediterranean Partnership and the Black Sea Economic Cooperation: A Comparative Analysis', Dış Politika/Foreign Policy 23/1-2-3-4 (1999) pp.75-100.

88. Selda Paydak, 'Avrupa-Akdeniz Ortaklığına Bakış: Avrupa Akdeniz Ortaklığı Bütünleşme Süreci ve Türkiye' [Viewing the Euro-Mediterranean Partnership: Euro-Mediterranean Partnership Integration Process and Turkey], Avrasya Dosyast 5/4 (1999) p.268.

89. Tayfur (note 87) p.75.

90. Ibid. p.81.

91. Ibid. p.83.

92. Ibid. p.81.

93. O. Tunander, 'A New Ottoman Empire? The Choice for Turkey: Euro-Asian Centre or National Fortress', Security Dialogue 26/4 (1995) p.416.

94. Unofficial translations of the EU 'harmonisation laws' are available at <http:// www.byegm.gov.tr/> (accessed 26 November 2002).

95. B. Buzan and T. Diez, 'The European Union and Turkey', Survival 41/1 (Spring 1999) p.42.

96. Pascal Clerc has recently noted that those who use geography to argue against Turkey's membership fail to see that 'boundaries are not natural but cultural constructs' designed to serve the projects of those who created them. Clerc's point is that the debate on the issue of Turkey's membership cannot be based on an understanding of geography that refuses to see the developments in its study. See Pascal Clerc, 'AB Coğrafyayı Bahane Etmesin' (The EU should not use Geography as an Excuse), Le Monde, translated and reprinted in Radikal, 24 November 2002.

97. 'Turkey Belongs in Europe', The Economist, 7 December 2002) p.13.

98. There is some awareness in Turkey of the need to rise up to this challenge. Turkey's policy makers attempted, in the wake of the 11 September attacks against New York and Washington, DC, to present Turkey as a contributor to a dialogue between civilisations by convening the OIC-EU (Organisation of Islamic Countries-European Union) Joint Forum in February 2002. See the collections of speeches delivered at the OIC-EU forum organized by the Turkish Ministry of Foreign Affairs at <www.mfa.gov.tr/OIC-EU-Forum.htm> (accessed 26 December 2002). The conference was aptly titled 'Civilisation and Harmony: The Political Dimension'. 